\title{
MAGNÉZIUMMAL ADALÉKOLT SZTÖCHIOMETRIKUS LÍTIUM- NIOBÁT HŐMÉRÉSKLETFÜGGŐ DIELEKTROMOS PARAMÉTEREI A TERAHERTZES TARTOMÁNYON
}

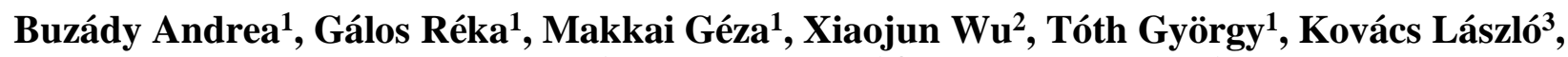 \\ Almási Gábor ${ }^{1}$, Hebling János ${ }^{1,4}$ és Pálfalvi László ${ }^{1}$
}

${ }^{1}$ Fizika Intézet, Pécsi Tudományegyetem, 7624 Pécs, Ifjúság útja 6., Magyarország

${ }^{2}$ School of Electronic and Information Engineering, Beihang University, Beijing, 100191, Chinag

${ }^{3}$ Wigner Fizikai Kutatóközpont, 1121 Budapest, Komkoly Thege Miklós út 29-33., Magyarország

${ }^{4}$ MTA-PTE, Nagyintenzitású Kutatócsoport, 7624 Pécs, Ifjúság útja 6., Magyarország

DOI: https://doi.org/10.14232/kvantumelektronika.9.5

\section{Bevezetés}

A nemlineáris optikai kristályokban létrehozott optikai egyenirányítás az egyik leggyakrabban alkalmazott módszer a terahertzes impulzusok előállítására. Sok alkalmazásnál extrém nagy energiájú és elektromos térerösségü terahertzes jelre van szükség. Az optikai tartományból a terahertzes tartományba való konverzió hatásfoka jelentősen függ az úgynevezett sebességillesztés feltételének teljesülésétől. Ez azt jelenti, hogy az optikai impulzus csoportsebessége és a keltett terahertzes impulzus fázissebessége meg kell egyezzen a kristályban. Ezt a feltételt a döntött impulzusfrontú gerjesztéssel lehet kielégíteni, még akár olyan kristályokban is, amelyekben nem egyezik meg a terahertzes és az optikai törésmutató [1]. A döntött impulzusfrontú gerjesztés esetén a sebességillesztés feltétele: $\quad v_{o p t}^{c s} \cos \gamma=v_{T H z}^{f}$, eszerint az optikai pumpáló impulzus csoportsebességének a THz-es impulzus terjedési irányára vett vetülete kell megegyezzen a THz-es impulzus fázissebességével. Az impulzusfront $\gamma$ szögű megdöntése szögdiszperzióval rendelkező optikai elemek alkalmazásával érhető el hangolhatóan.

A THz keltésben gyakran használt kristály a lítium-niobát $\left(\mathrm{LiNbO}_{3}, \mathrm{LN}\right)$. A döntött impulzusfrontú elrendezés paramétereinek tervezésénél ismerni kell a nemlineáris kristály terahertzes tartományú abszorpciós együtthatójának és a törésmutatójának frekvenciafüggvényét. Korábbi tanulmányokból ismert, hogy a kristály sztöchiometriája és magnéziummal való adalékolása befolyásolja a dielektromos paramétereket [2,3]. Ezen tulajdonságok optimalizálásán túlmenően a hőmérséklet csökkentésével is kedvezőbbé lehet tenni a terahertzkeltés hatásfokát, ahogy azt $6 \mathrm{~mol} \% \mathrm{Mg}$ adalékolású kongruens lítium-niobát (cLN:6.0\%Mg) esetén már vizsgálták [4]. Munkánkban a 0,7 mol\% Mg-adalékolású sztöchiometrikus lítium-niobát hőmérsékletfüggő dielektromos paramétereinek terahertzes tartományú meghatározását tüztük ki célul, mert a szobahőmérsékletü mérések alapján a terahertzes sugárzás generálásához ez még kedvezőbbnek tủnik, mint a kongruens kristály.

Az eredmények felhasználásával megadtunk egy kompakt formulát is a törésmutató és az abszorpciós együttható frekvenciafüggvényének a rekonstruálásához. Bár a függvény nem valós fizikai kölcsönhatásokat leíró modellböl [5] származik, jól használható nagy energiájú terahertzes források tervezésénél a hőmérsékletfüggő sebességillesztési szög meghatározásához [6,7].

\section{Mérés és adatfeldolgozás}

A 0,7\%-ban magnéziummal adalékolt $600 \mu$ m vastagságú sztöchiometrikus LN kristály

(0,7\%Mg:sLN) vizsgálatához szükséges időtérbeli jelek mérését Tong Lin és Xiaojun Wu (School 
of Electronic and Information Engineering, Beihang University, Beijing, 100191, China) végezték egy THz-TDS berendezéssel 4-460 K hőmérsékleten ordinárius és extraordinárius polarizációs irányban is.

A szélessávú lineárisan polarizált THz-es impulzus keltése gallium-arzenid (GaAs) fotovezető antennával történt. Ehhez 70 fs-os lézerimpulzusokat alkalmaztak, melyek forrása egy $80 \mathrm{MHz}$ ismétlési frekvenciájú titán-zafír lézer volt. A THz-es jelet parabolikus tükrök fókuszálták a mintára, majd a detektorra. A detektálás elektrooptikai mintavételezéssel történt.

A minta, az emitter és a detektor is egy vákuumkamrában volt elhelyezve, amelyben körülbelül $10^{-5}$ mbar nyomás volt biztosított a hütés és a mérés során. A kriogenikus hőmérsékletre való hütéshez folyékony héliumot alkalmaztak. A mintát a THz-es nyaláb fókuszsíkjába helyezve megmérték a rajta átmenő jelet ordinárius polarizációs irányban, majd $90^{\circ}$-al elforgatva extraordinárius polarizációs irányban is. Mindkét irányban több különböző - ordinárius irányban: $4 \mathrm{~K}, 20 \mathrm{~K}, 40 \mathrm{~K}, 60 \mathrm{~K}, 100 \mathrm{~K}, 140 \mathrm{~K}, 180 \mathrm{~K}, 220 \mathrm{~K}, 260 \mathrm{~K}, 300 \mathrm{~K}, 340 \mathrm{~K}, 380 \mathrm{~K}, 420 \mathrm{~K}, 460 \mathrm{~K}$; extraordinárius irányban: $4 \mathrm{~K}, 20 \mathrm{~K}, 40 \mathrm{~K}, 60 \mathrm{~K}, 80 \mathrm{~K}, 100 \mathrm{~K}, 120 \mathrm{~K}, 140 \mathrm{~K}, 160 \mathrm{~K}, 180 \mathrm{~K}, 220 \mathrm{~K}$, 240 K, 260 K, 280 K, 300 K, 320 K, 340 K, 360 K, 380 K, 420 K, 460 K - hömérsékleten történtek mérések. Referenciajelet (üres téren átmenő jel) a minta ordinárius irányban történő mérése közben több hőmérsékleten $(100 \mathrm{~K}, 180 \mathrm{~K}, 300 \mathrm{~K}, 420 \mathrm{~K})$ is mértek. Ezen jelek között nem tapasztalható jelentős változás, így a továbbiakban csak $300 \mathrm{~K}$ hőmérsékleten készült referenciajel.

A minta anyagi paramétereinek meghatározásához a mintán átmenő és üres téren átmenő (referencia) THz-es jel elektromos térerősségének időbeli lefutására van szükség. Az időtérbeli jel Fouriertranszformáltja adja a komplex spektrumot, azaz a térerősség amplitúdóját és fázisát. A mintára és a referenciára jellemző spektrumok $\left(E_{\text {sample }}(v) ; E_{\text {ref }}(v)\right)$ összehasonlításával a következőképpen határozható meg az anyagra jellemző frekvenciafüggő abszorpciós együttható és törésmutató. A Fourier-transzformáltakból számított átviteli függvény:

$$
H(v)=\frac{E_{\mathrm{sample}}(v)}{E_{\mathrm{ref}}(v)}
$$

Ezt felhasználva adódik a $d$ vastagságú mintára az $n(v)$ törésmutató, annak ismeretében pedig az $\alpha(v)$ abszorpciós együttható:

$$
n(v)=\arg (H(v)) \cdot \frac{c}{2 \pi v d}+1 \quad \alpha(v)=\frac{4 \pi v \kappa(v)}{c}=\frac{2}{d} \ln \left(\frac{1}{|H(v)|} \frac{4 n(v)}{(n(v)+1)^{2}}\right)
$$

\section{Eredmények}

Az 1. ábrán a terahertzkeltés szempontjából fontosabb extraodinárius polarizációjú törésmutató és abszorpciós együttható frekvenciafüggvénye látható néhány kiválasztott hőmérsékleten. Az időtérbeli mérésekből meghatározható adatokat polinom függvénnyel illesztettük. 

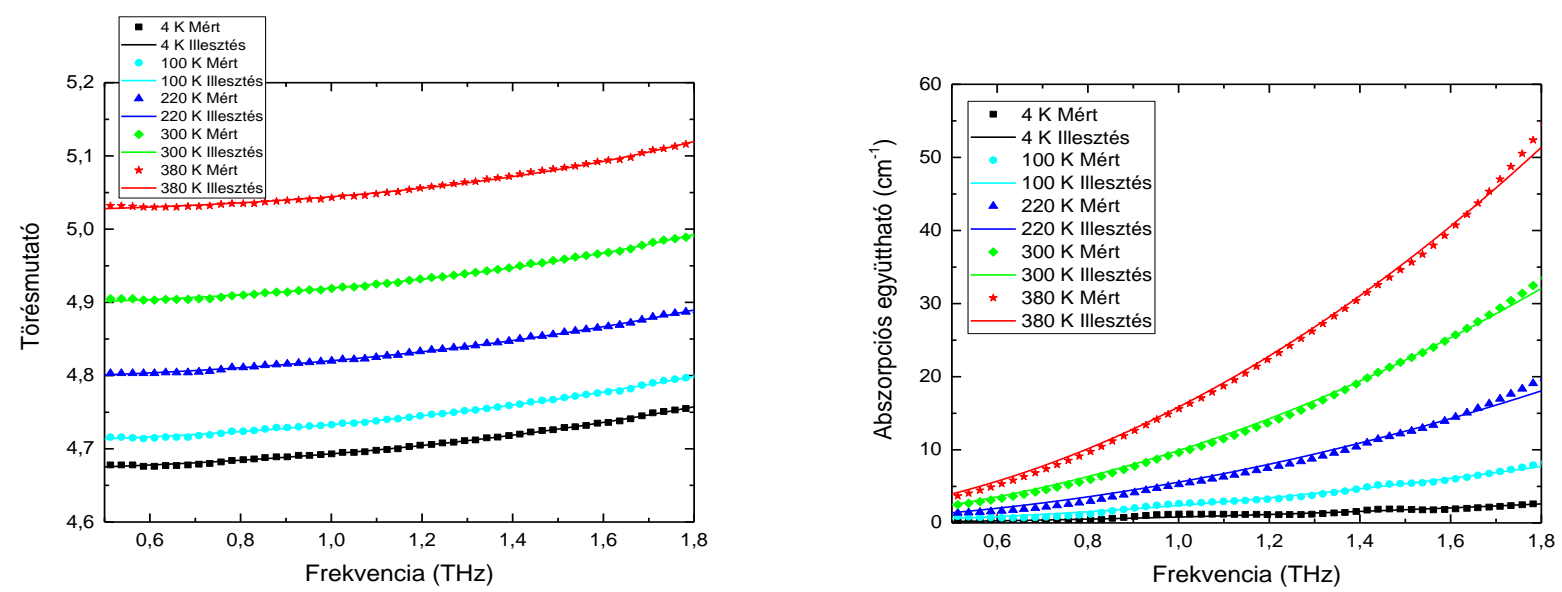

1. ábra

0,7\%Mg:sLN extraordinárius törésmutató és abszorpciós együttható frekvenciafüggése és polinomos illesztése

Tapasztalataink alapján az abszorpciós együttható frekvenciafüggését másodfokú függvénnyel lehet jól leírni:

$$
\alpha(v, T)=B(T) v^{2}
$$

ahol a $B(T)$ illesztési paraméter a hőmérséklet másodfokú függvénye:

$$
B(T)=a_{0}+b_{0} T^{2}
$$

Így az $\alpha(v, T)=\left(a_{0}+b_{0} T^{2}\right) v^{2}$ összefüggéssel az adott polarizációs irányban bármely hőmérsékleten széles frekvenciatartományon megadható az abszorpciós együttható mindössze két konstans segítségével, melyek az 1. táblázatban és a 2. ábrán láthatóak.

\begin{tabular}{|c|c|c|}
\hline & $a_{0}\left(\mathrm{~cm}^{-1} \mathrm{THz}^{-2}\right)$ & $b_{0}\left(10^{-4} \mathrm{~cm}^{-1} \mathrm{~K}^{-2} \mathrm{THz}^{-2}\right)$ \\
\hline Extraordinárius & 0,69 & 1,07 \\
\hline Ordinárius & 2,48 & 1,72 \\
\hline
\end{tabular}

\section{1. táblázat}

Az abszorpciós együttható frekvencia- és hömérsékletfüggését egyszerre jellemzö konstansok extraordinárius és ordinárius polarizációs irányban
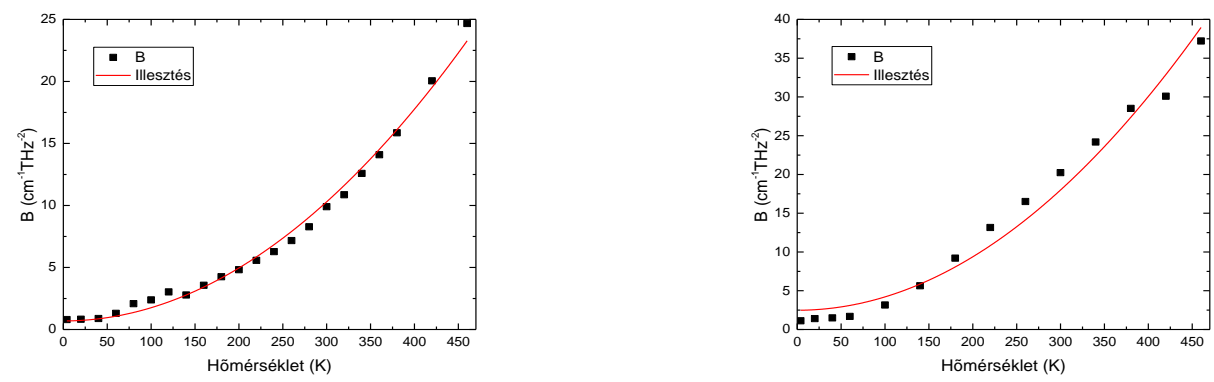

2. ábra 0,7\%Mg:sLN B(T) függvénye extraordinárius és ordinárius polarizációirányra 
A frekvenciafüggő törésmutató adatok jól közelíthetők bármely hőmérsékleten a következő negyedrendủ polinommal:

$$
n(v)=A+B v^{2}+C v^{4}
$$

A törésmutató frekvencia- és hőmérsékletfüggése - az abszorpciós együtthatóéval ellentétben - nem jellemezhetö az összes frekvenciára egyszerre érvényes egyszerü formulával. Két kiválasztott $(0,8 \mathrm{THz}$ és 1,6 THz) frekvencián azonban a hőmérsékletfüggés megadható egy másodfokú függvénnyel. A 2. táblázatban és a 2 ábrán az $n(T)=A+B T^{2}$ polinommal történt illesztés eredményei láthatóak.

\begin{tabular}{|c|c|c|c|c|}
\hline & \multicolumn{2}{|c|}{$0,8 \mathrm{THz}$} & \multicolumn{2}{c|}{$1,6 \mathrm{THz}$} \\
\hline & $A$ & $B\left(10^{-6} \mathrm{~K}^{-2}\right)$ & $A$ & $B\left(10^{-6} \mathrm{~K}^{-2}\right)$ \\
\hline Extraordinárius & 4,69 & 2,35 & 4,75 & 2,38 \\
\hline Ordinárius & 6,42 & 1,79 & 6,62 & 1,83 \\
\hline
\end{tabular}

\section{2. táblázat}

A hömérséklettöl függö törésmutató illesztési paraméterei mindkét polarizációs irányban két kiválasztott frekvencián
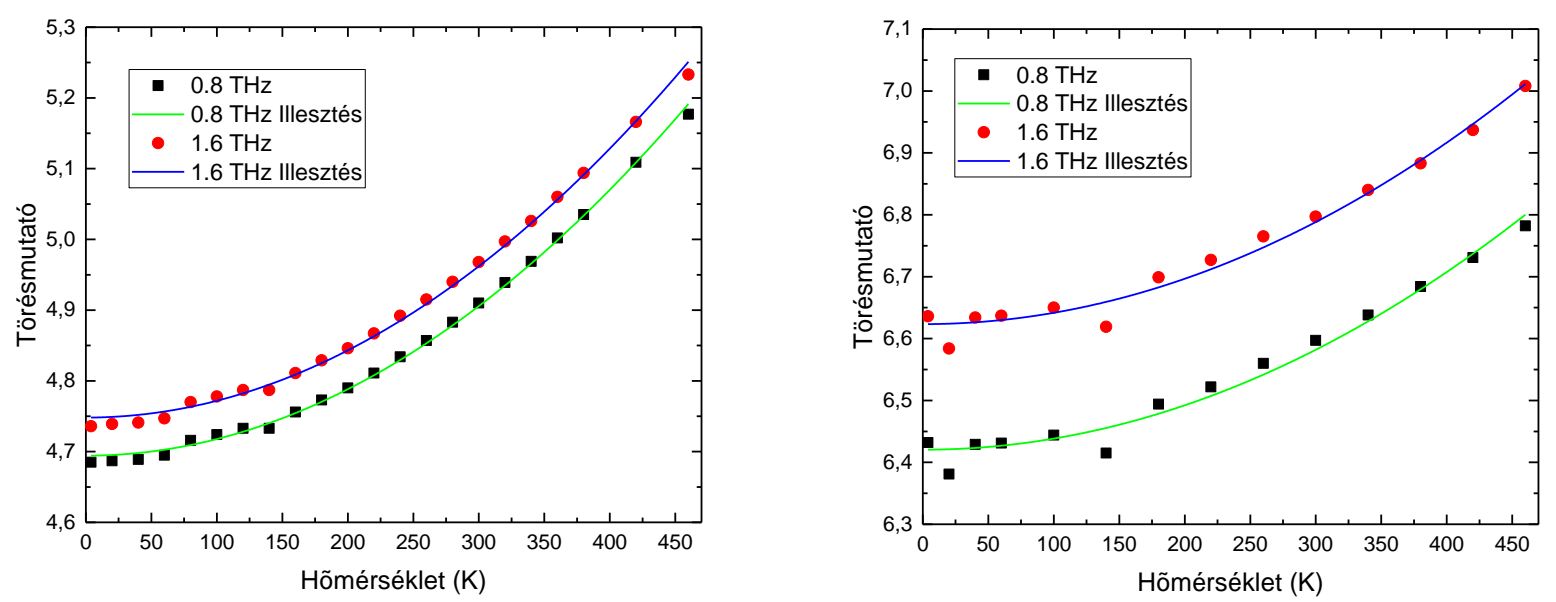

3. ábra

0,7\%Mg:sLN extraordinárius és ordinárius törésmutató hömérsékletfüggése

A döntött impulzusfrontú THz-keltés megvalósításához szükséges nemcsak az impulzusfront dőlésszögének, hanem a diffrakciós szög és a rácsra való beesési szög ismerete is.

Az optimális elrendezés tervezéséhez az impulzusfont dőlésszögét (fázisillesztési szög) (4. ábra) az $v_{o p t}^{c s} \cos \gamma=v_{T H z}^{f}$ egyenlet alapján határoztuk meg, amelyhez a THz-es fázissebességet a 0,8 és 1,6 THz frekvencián mért törésmutató-adatokból számoltuk az összes hőmérsékleten. Az optikai impulzus csoportsebességének meghatározásához Gayer korábbi eredményeit [8] használtuk. Ezen paraméterek ismeretében a diffrakciós szög és az optikai rácsra való beesés szöge (5. ábra) 0,8 és 1,6 THz frekvencián több hőmérsékleten a következő összefüggésekkel határozhatók meg. 


$$
\begin{gathered}
\sin \theta_{d}=\frac{\lambda_{0}}{n\left(\lambda_{0}\right) n_{g}\left(\lambda_{0}\right) p} a \\
\sin \theta_{i}=\frac{\lambda_{0}}{p}-\sin \theta_{d}
\end{gathered}
$$

ahol $\theta_{d}$ a diffrakciós szög, $\theta_{i}$ a beesési szög, $p$ a rácskarcolatok távolsága, $\lambda_{0}$ a pumpálási hullámhossz, $n\left(\lambda_{0}\right)$ a fázistörésmutató a pumpálási hullámhosszon, $n_{g}\left(\lambda_{0}\right)$ a csoporttörésmutató a pumpálási hullámhosszon, amely a fázistörésmutató ismeretében $n_{g}=n-\lambda \frac{d n}{d \lambda}$ módon számolható, az a paraméter pedig a következő [6,7]:

$$
a=\frac{n^{2}\left(\lambda_{0}\right) n_{g}\left(\lambda_{0}\right) p}{2 \lambda_{0}} \sqrt{\frac{\lambda_{0}^{2}}{n_{g}^{2}\left(\lambda_{0}\right) p^{2} \tan ^{4} \gamma}+\frac{4}{n^{2}\left(\lambda_{0}\right)}}-\frac{n^{2}\left(\lambda_{0}\right)}{2 \tan ^{2} \gamma}
$$

A számolás során $1030 \mathrm{~nm}$ pumpálási hullámhosszat és a rácskarcolatok sủrüségének $1500 \mathrm{karcolat} / \mathrm{mm}-\mathrm{t}$ feltételeztünk [8].
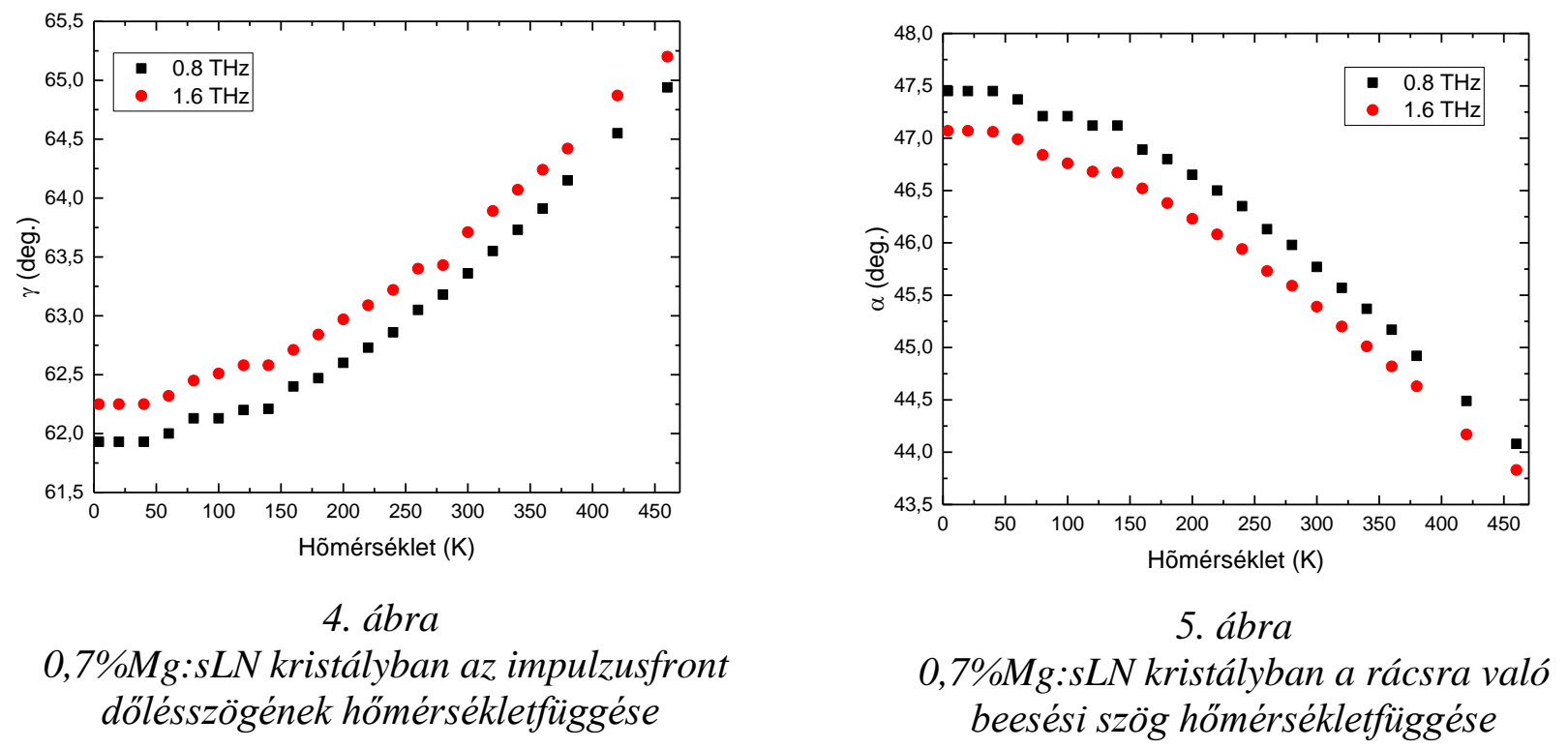

\section{4. Összefoglalás}

0,7\%-ban magnéziummal adalékolt sLN kristály dielektromos jellemzőinek frekvencia- és hőmérsékletfüggését $0,5-1,8 \mathrm{THz}$ frekvenciatartományon ordinárius és extraordinárius polarizációs irányban vizsgálva megállapítható, hogy THz-es jel keltése szempontjából elönyösebb lehet cLN kristály helyett sLN kristályt alkalmazni, mivel a törésmutató és az abszorpciós együttható értékei is kisebbek mindkét polarizációs irányban. Az abszorpciós együttható nemcsak a kristály sztöchiometriájával és magnéziummal való adalékolással csökkenthető, hanem kriogenikus hőmérsékletre való hütéssel is. A hőmérséklet csökkenésével a minta törésmutatója és abszorpciós együtthatója is csökken a teljes megbízható frekvenciatartományon. $100 \mathrm{~K}$ hőmérséklet alatt azonban nem tapasztalható jelentős változás a hőmérséklet csökkenésével sem a törésmutatóban, sem az abszorpciós együtthatóban egyik polarizációs irány esetén sem. Tehát a további alkalmazásokhoz nem szükséges $100 \mathrm{~K}$ hőmérséklet alá hüteni a mintát. 
Továbbá, tapasztalataink alapján az abszorpciós együttható frekvencia- és hőmérsékletfüggése egyszerre leírható egy kompakt formulával, amely matematikailag is alátámasztható. Így adott minta adott polarizációs irányában bármely hőmérsékleten széles frekvenciatartományon megadható az abszorpciós együttható két illesztési konstans segítségével.

A törésmutató frekvenciafüggése negyedfokú polinommal közelíthető, míg a hőmérsékletfüggése adott frekvencián kiszemelve értékeket - másodfokú polinommal írható le.

A fázisillesztési szög és a rácsra való beesési szög hőmérsékletfüggése azt mutatja, hogy döntött impulzusfrontú THz-keltés elrendezésének optimalizálásakor figyelembe kell venni a hőmérséklet hatását is.

\section{Köszönetnyilvánítás}

A munkát az EFOP-3.6.2-16-2017-00005 azonosító számú, Ultragyors fizikai folyamatok atomokban, molekulákban, nanoszerkezetekben és biológiai rendszerekben címü projekt támogatta.

\section{Irodalom}

[1] J. Hebling J. G. Almási, I. Z. Kozma, and J. Kuhl, "Velocity matching by pulse front tilting for large-area THz-pulse generation," Opt. Express 10, 1161-1166 (2002)

https://doi.org/10.1364/OE.10.001161

[2] L. Pálfalvi, J. Hebling, J. Kuhl, A. Péter, and K. Polgár, "Temperature dependence of the absorption and refraction of Mg-doped congruent and stoichiometric LiNbO3 in the THz range," J. Appl. Phys. 97, 123505 (2005)

https://doi.org/10.1063/1.1929859

[3] M. Unferdorben, Z. Szaller, I. Hajdara, J. Hebling, and L. Pálfalvi, "Measurement of Refractive Index and Absorption Coefficient of Congruent and Stoichiometric Lithium Niobate in the Terahertz Range,” J. Inf Millim TE 36, 1203-1209 (2015)

https://doi.org/10.1007/s10762-015-0165-5

[4] X. Wu, C. Zhou, W. R. Huang, F. Ahr, and F. X. Kärtner, “Temperature dependent refractive index and absorption coefficient of congruent lithium niobate crystals in the terahertz range," Opt. Express 23, 29729-29737 (2015)

https://doi.org/10.1364/OE.23.029729

[5] M. Schall, H. Helmand, and S. R. Keiding, "Far infrared properties of electro-optic crystals measured by THz time-domain spectroscopy," J. Infrared Millim. Terahertz Waves 20, 595-604 (1999)

https://doi.org/10.1023/A:1022636421426

[6] J. A. Fülöp, L. Pálfalvi, G. Almási, and J. Hebling, "Design of high-energy terahertz sources based on optical rectification," Opt. Express 18, 12311-12327 (2010)

https://doi.org/10.1364/OE.18.012311

[7] J. A. Fülöp, L. Pálfalvi, G. Almási, and J. Hebling, "Design of high-energy terahertz sources based on optical rectification: erratum,” Opt. Express 19, 22950 (2011)

https://doi.org/10.1364/OE.19.022950 
[8] O. Gayer, Z. Sacks, E. Galun, and A. Arie, „Temperature and wavelength dependent refractive index equations for MgO-doped congruent and stoichiometric LiNbO3," Appl. Phys. B 91, 343-348, (2008)

https://doi.org/10.1007/s00340-008-2998-2 